\title{
Developmental Expression of Vasoactive and Growth Factors in Human Lung. Role in Pulmonary Vascular Resistance Adaptation at Birth
}

\author{
MARILYNE LÉVY, CHRISTELLE MAUREY, A. TUAN DINH-XUAN, PASCAL VOUHÉ, AND \\ DOMINIQUE ISRAËL-BIET
}

\begin{abstract}
UPRES EA220 [M.L., C.M.,D.I.-B.], Laboratoire d'Immunologie Pulmonaire, Faculté de Médecine, Paris V, France, UPRES EA2511 [A.T.D.-X.], Laboratoire de Physiologie Respiratoire, Faculté de Médecine, Paris V, France, Service de Chirurgie Cardiaque Pediatrique [P.V.], Hopital Necker-Enfants Malades,
\end{abstract} Paris, France

\begin{abstract}
The factors that mediate the postnatal fall in pulmonary vascular resistance, which is crucial for normal gas exchange, are not fully understood. The endothelium has been implicated in this phenomenon, through the release of vasorelaxant factors such as nitric oxide (NO). Human pulmonary expression of endothelial NO synthase increases up to $31 \mathrm{wk}$ of gestation, together with vascular endothelial growth factor (VEGF), and both factors potently mediate pulmonary angiogenesis and vasorelaxation. During the perinatal period, when pulmonary vasodilatation is maximal, endothelial NO synthase and VEGF are weakly expressed. This raises the involvement of vasorelaxant factors other than NO at birth. One candidate is endothelialderived hyperpolarizing factor, which induces smooth muscle cell hyperpolarization by activating $\mathrm{K}_{\mathrm{ATP}}$ channels. The marked vasorelaxation induced by activation of these channels in newborn animals, and their strong perinatal expression in the human lung, suggest their involvement during this phase. Another candidate is endothelin (ET)-1, together with its receptors ET-A and ET-B. ET-A receptors are located exclusively on smooth muscle cells and mediate vasoconstriction, whereas ET-B receptors mediate vasoconstriction when located on smooth muscle cells and
\end{abstract}

\section{ABSTRACT}

vasodilatation when located on endothelial cells. ET-B receptors, which are strongly expressed in the human fetal lung both at the end of gestation and after birth, may be involved in perinatal pulmonary vasodilatation. Thus, in human fetal lung, $\mathrm{K}_{\mathrm{ATP}}$ channels and ET-B receptors could be important in mediating the perinatal pulmonary vasodilatation crucial for adapting the pulmonary circulation to extrauterine life. (Pediatr Res 57: 21R-25R, 2005)
Abbreviations
BMP, bone morphogenic protein
EDHF, endothelium-derived hyperpolarizing factor
eNOS, endothelial nitric oxide synthase
ET-1, endothelin-1
ET-A, type A endothelin receptor
ET-B, type B endothelin receptor
FGF, fibroblast growth factor
$\mathbf{K}_{\mathbf{A T P}}$, ATP-sensitive potassium channel
NO, nitric oxide
PPHN, persistent pulmonary hypertension of the neonate
TGF, transforming growth factor
VEGF, vascular endothelial growth factor

Fetal pulmonary circulation is characterized by high vascular resistance: $<10 \%$ of ventricular output enters the lungs (1). The underlying mechanisms likely involve physical factors such as the lack of ventilation and low oxygen tension. An imbalance between vasorelaxant and vasoconstrictor mediators (2-4) (Fig. 1) is also likely. These mediators, derived from the endothelium, have either vasorelaxant effects (NO, prostacyclin, and EDHF) or vasoconstrictive effects (e.g. ET-1) (5-7).

Received August 9, 2004; accepted January 13, 2005.

Correspondence: Marilyne Levy, M.D., Ph.D., Service de Chirurgie Cardiaque Pediatrique, Hopital Necker Enfants Malades, 149 rue de Sevres, 75015 Paris, France; e-mail: marilyne.levy@nck.ap-hop-paris.fr

This work was supported by Société Française de Cardiologie (Hélène de Marsan Grant).
VEGF, crucial for endothelial growth and angiogenesis, also exerts a potent vasorelaxant effect by interacting with the NO pathway (8). Although these endothelial vasoactive factors and growth factors appear to be involved in regulating pulmonary vascular tone during fetal life and after birth, human data are scarce and conflicting data have been obtained in animal models.

\section{THE FETAL PULMONARY CIRCULATION}

Fetal lung development is classically classified into five stages (9), namely embryonic (up to $7 \mathrm{wk}$ ), pseudoglandular (7-16 wk), canalicular (16-24 wk), saccular (24-35 wk), and alveolar $(>35 \mathrm{wk})$. 


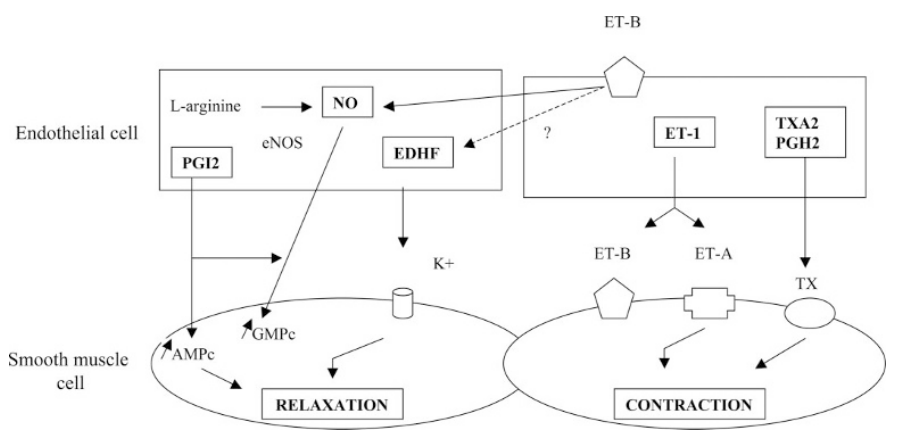

Figure 1. Diagram showing the different pathways involved in neonatal pulmonary vascular tone.

The lungs originate from the foregut endoderm. These endodermal buds branch and differentiate within the surrounding mesoderm, giving rise to the airways, blood vessels, and alveoli. Cross-talk between epithelial and mesenchymal cells is crucial for lung differentiation. Factors involved in this crosstalk include TGF- $\beta$, BMP-4, IGF, FGF, and fibronectin $(9,10)$. The lung vasculature develops through two processes, namely vasculogenesis, in which new blood vessels form in situ from angioblasts, and angiogenesis, in which new vessels sprout from existing ones (11). Vessel development begins at the outset of lung development, requires epithelial-mesenchymal cross-talk, and is inextricably linked to airway development (11-13). In the fetus, the bulk of right ventricular output is diverted away from the lungs through the patent ductus arteriosus to the aorta (6), as gas exchange occurs in the placenta. The involvement of endothelial factors in this high fetal pulmonary vascular resistance has been widely studied in animals $(6,7)$, but their ontogeny is poorly documented in the human fetal lung.

In fetal lambs, ET-1 appears to be involved in pulmonary vasoconstriction $(14,15)$. In this model, pulmonary ET-1 levels fall markedly before birth, yet pulmonary vascular resistance remains high. This points to the involvement of factors other than ET-1. In addition, the role of ET-1 depends on which of its receptors is activated (16-19). ET-A activation induces vasoconstriction, whereas ET-B activation induces vasoconstriction when the receptors are located on smooth muscle cells and vasodilatation when they are located on endothelial cells. In fetal lambs, ET-B receptors are strongly expressed in the perinatal period and their blockade attenuates $\mathrm{O}_{2}$-induced vasodilatation $(15,18,19)$, whereas in newborn piglets ET-B receptor activation induces pulmonary vasodilatation (20). These data strongly support a vasodilatory role of ET-B receptors in the perinatal period. As regards the human fetal lung, we have found that the expression of both ET-1 and ET-A is stable throughout gestation, whereas ET-B expression increases in mid-term and remains high until birth (21). ET-B receptors may thus have an important role in perinatal vasodilation. Prostaglandin $I_{2}$ is synthesized primarily in vascular endothelial cells and exerts its vasodilatory action by activating adenyl cyclase through receptor $\mathrm{G}$ protein-coupled mechanisms. $\mathrm{PGI}_{2}$ production increases gradually throughout gestation, but its inhibition does not markedly change resting pulmonary vascular resistance (6). In addition, the ductus arteriosus is particu- larly sensitive to $\mathrm{PGE}_{2}$ at mid-term and less so at the end of gestation, suggesting only a modest effect on vascular tone in the perinatal period (22). This increased sensitivity during fetal life could explain the high incidence of patent ductus arteriosus in preterm infants.

NO is synthesized by endothelial cells after eNOS activation. In fetal lambs, inhibition of NO synthesis increases resting pulmonary vascular resistance, strongly pointing to $\mathrm{NO}$ involvement in maintaining low pulmonary vascular tone in basal conditions $(7,23,24)$. In this model, eNOS expression peaks three-quarters of the way through gestation and falls before birth, whereas it peaks at birth in piglets and after birth in rats (24-27). Differences in the chronology of lung parenchymal and vascular development between species may account for these differences in eNOS expression kinetics (2830). The temporal relationship between airway and pulmonary vasculature development is firmly established in animals (24) and was recently confirmed in humans $(9,12)$. In human fetal lung, the concomitance of the increase in eNOS expression and the onset of alveolarization points to an important role of eNOS in airway maturation (31). Indeed, in addition to its vasorelaxant effect, the NO pathway is involved in both angiogenesis and lung development (31-33). However, eNOS-null mice have abnormal lung development but a functional pulmonary circulation in adulthood, suggesting that eNOS is not vital for angiogenesis, at least in this model $(33,34)$. No data are available on human eNOS ontogeny. We recently observed a gradual increase in eNOS expression in the human fetal lung until $31 \mathrm{wk}$ of gestation, followed by a sharp decrease close to birth (21). As in other animals, peak eNOS expression matches the onset of alveolarization in humans. This, together with very weak eNOS expression at birth, suggests a role in lung maturation rather than in neonatal vasodilatation. It is noteworthy in this respect that prenatal glucocorticoid administration, while activating lung maturation, also increases pulmonary eNOS expression in fetal lambs (35) through an unknown mechanism.

VEGF potently induces endothelial cell growth in vitro and angiogenesis in vivo (36-39). VEGF expression is stimulated by TGF- $\beta$, hypoxia, and shear stress $(39,40)$. Recent studies indicate that VEGF acts as a paracrine mediator of angiogenesis in the developing lung $(36,41,42)$, whereas abundant growth of intra-acinar capillaries coincides with alveolar development in lambs and humans (12,30). VEGF is also involved in epithelial cell proliferation in human fetal lung, highlighting its role as both an autocrine and a paracrine growth factor $(41,43,44)$. VEGF is detected in endothelial and bronchial epithelial cells of the fetal and mature human lung, but only in bronchial epithelial cells of term infants, indicating a paracrine role after birth (41). Although the role of VEGF in lung development appears to be crucial, little is known of its human ontogeny. In the above-mentioned study, we found that VEGF expression followed the same pattern as eNOS, with an increase between the canalicular and saccular stages, then a sharp decrease at the alveolar stage (21). A number of studies have described parallel effects of NO and VEGF, which both have vasodilative and angiogenic properties (31-33). Their peak expression in the human lung at $31 \mathrm{wk}$ of gestation, just 
before the alveolar stage, suggests their possible involvement in alveolar development. This is in keeping with the fact that premature infants born after this time point do not usually require mechanical ventilation $(45,46)$.

\section{THE NEONATAL CIRCULATION}

The mechanisms underlying the fall in pulmonary vascular resistance and the immediate increase in pulmonary blood flow at birth are unclear. The decrease in pulmonary vascular resistance is tightly regulated by an interplay between metabolic and mechanical factors triggered by the ventilatory and circulatory changes that occur at birth, including closure of the ductus arteriosus through decreased sensitivity to prostaglandins (22). The initial rapid vasodilatation is at least partly stimulated mechanically by lung inflation and by the increase in oxygen tension, but endothelial factors also play a critical role.

Animal studies. Physical expansion of the fetal lamb lung, with no concurrent change in oxygen tension, induces a modest decrease in pulmonary vascular resistance, partly due to prostaglandin synthesis $(6,47-49)$. Ventilation of near-term lambs with air or oxygen induces marked pulmonary vasodilatation, possibly through the release of NO, prostaglandins, bradykinin, or EDHF. Prostaglandin inhibition attenuates the fall in pulmonary vascular resistance induced by lung inflation but not that induced by oxygenation, suggesting only minor involvement of prostaglandins in neonatal pulmonary vasodilatation (6). NO appears to be more important, as eNOS inhibition in lambs attenuates the increase in pulmonary blood flow at birth $(21,47)$. In newborn piglets, however, NO-dependent vasodilatation in response to acetylcholine is totally absent at birth and only appears at $3 \mathrm{~d}$ of age, even though eNOS expression increases after $1 \mathrm{~d}$ of age, suggesting a dysregulation of $\mathrm{NO}$ pathway rather than absence of eNOS $(20,50,51)$. Vasorelaxant factors other than $\mathrm{NO}$, such as prostacyclins, bradykinin, and $\mathrm{K}+$ channel openers, might therefore be involved during the first hours of life in this model. Inhibition of these factors in fetal lambs reduces the pulmonary blood flow induced by lung expansion but not that induced by oxygenation (48). Bradykinin blockade, on the other hand, has no effect on the fall in pulmonary vascular resistance (52). Hyperpolarization of smooth muscle cells through potassium channel activation is therefore likely to be involved. Various types of $\mathrm{K}+$ channels have been described in vascular smooth muscle, including voltage-activated $\mathrm{K}+$ channels $(\mathrm{Kv}), \mathrm{Ca} 2+$-activated $\mathrm{K}+$ channels (Kca), pH-sensitive $\mathrm{K}+$ channels (TASK), and ATPsensitive $K+$ channels $\left(K_{\text {ATP }}\right)$ (53). The respective roles of these $\mathrm{K}+$ channels is controversial, although oxygen-induced pulmonary vasodilatation is markedly inhibited by blocking $\mathrm{K}_{\mathrm{CA}}$ and $\mathrm{K}_{\mathrm{ATP}}$ channels in near-term fetal lambs (54). $\mathrm{K}+$ channel expression is controversial in experimental pulmonary hypertension of newborn animals, and appears to be strongly dependent on the model used. Indeed, $\mathrm{Kv}$ and $\mathrm{Kca}$ expression is reduced in the rat model of nitrofen-induced congenital diaphragmatic hernia (55), $\mathrm{Kv}$ expression is not modified in shunted lambs, and $\mathrm{K}_{\mathrm{Ca}}$ expression fell in some studies and rose in others (56-58). The role of $\mathrm{K}_{\mathrm{ATP}}$ channels in neonatal pulmonary vasodilation is poorly documented. $\mathrm{K}_{\mathrm{ATP}}$ channel openers induce strong vasorelaxation in both newborn lambs and piglets, and this effect is partly inhibited by the endothelium, as we and others have shown $(20,59,60)$. This effect was initially attributed partly due to a lack of NO activity (61), although one alternative is an excess of ET-1. Indeed, plasma levels and pulmonary expression of ET-1 are high in the newborn piglet then fall to adult levels after 3 d $(20,61)$. Furthermore, we have found that the vascular relaxation induced by $\mathrm{K}_{\mathrm{ATP}}$ openers is potentiated by specific ET-A receptor blockade $(20,60)$, an effect that had previously only been reported in cerebral arteries and the heart $(62,63)$. ET-1, strongly expressed in both normal and hypertensive lungs, might therefore inhibit neonatal pulmonary vasodilation via its ET-A receptors.

Human studies. Published data on the ontogeny of vasoactive factors and growth factors in the human lung are scarce. We have shown that eNOS and VEGF, both involved in pulmonary angiogenesis and vasorelaxation, are weakly expressed in the perinatal period (21). These data suggest the involvement of vasorelaxant factors other than NO in human neonatal pulmonary vasodilatation. Potassium channels are good candidates, but pharmacological and functional studies of human fetal lungs are difficult, for obvious reasons. In a search for indirect evidence, we examined $\mathrm{K}_{\mathrm{ATP}}$ channel subunit Kir 6.1 expression in lung tissues from aborted human fetuses. Interestingly, the subunit was strongly expressed on vascular smooth muscle cells in both near-term fetuses and newborns (Fig. 2) (64). These are the first data pointing to a crucial role of $\mathrm{K}_{\mathrm{ATP}}$ channels in human pulmonary vascular adaptation at birth.

\section{THERAPEUTIC IMPLICATIONS}

PPHN is a severe disorder, for which current treatments are disappointing. Inhaled NO is a selective pulmonary vasodilator with a short half-life. necessitating continuous administration $(65,66)$. Inhaled NO has improved the prognosis of PPHN, but some patients are resistant and others remain dependent (67). Continuous prostacyclin infusion attenuates the clinical symptoms and reduces pulmonary pressure but has troublesome systemic effects (68). Bosentan, a drug antagonizing the effects of ET-1, appears to be as effective as prostacyclin in adults and is also better tolerated (69). However, bosentan is a nonselec-
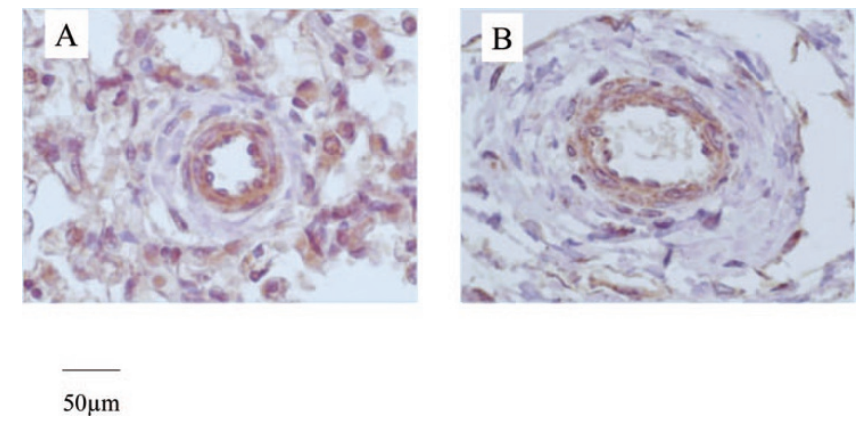

Figure 2. Immunostaining for Kir 6.1 in lungs of fetuses at $31 \mathrm{wk}(A)$ and neonate $(B)$. Kir 6.1 subunit of $\mathrm{K}_{\mathrm{ATP}}$ channels is expressed by smooth muscle cells and epithelial cells. Magnification is $\times 250$. 
tive endothelin antagonist blocking both ET-A and ET-B receptors (70). It has been suggested that ET-B receptors, which are strongly expressed in the human neonatal lung, might have a vasorelaxant effect $(18,19)$. The use of selective ET-A blockers might therefore be preferable in PPHN. The phosphodiesterase V inhibitor sildenafil, which acts by promoting cGMP accumulation in smooth muscle cells, facilitates NO weaning of patients with PPHN and is also effective on adult pulmonary hypertension $(71,72)$. Trials of this drug are now underway in infants. Finally, $\mathrm{K}_{\mathrm{ATP}}$ channel openers, currently used in coronary heart disease (73), have never been tested in pulmonary hypertension. Their enhanced vasorelaxant effects in experimental models of PPHN call for clinical trials in human PPHN $(59,60)$.

\section{SUMMARY}

The mechanisms underlying pulmonary vasodilatation at birth are poorly understood in humans. Expression of eNOS and VEGF peaks just before the alveolar stage of lung development, indicating a key role of these two mediators in pulmonary maturation. In the perinatal period, when pulmonary vasodilatation is maximal, eNOS and VEGF expression is very low and ET-1 and ET-1 receptor expression is very high. This suggests that mediators other than NO participate in the marked pulmonary vasodilatation occurring in human newborns. ET-B receptors, strongly expressed in the human lung from mid-gestation until birth, might have potent vasodilatory effects in the newborn. $\mathrm{K}_{\mathrm{ATP}}$ channels mediate vasorelaxation in newborn animals and are strongly expressed throughout human lung development, but their role in the adaptation of pulmonary vascular resistance at birth remains to be established.

\section{REFERENCES}

1. Rudolph AM, Heymann MA 1970 Circulatory changes during growth in the feta lamb. Circ Res 26:289-299

2. Cassin S 1987 Role of prostaglandins, thromboxanes, and leukotrienes in the contro of the pulmonary circulation in the fetus and newborn. Semin Perinatol 11:53-63

3. Enhorning G, Adams FH, Norman A 1966 Effect of lung expansion on the fetal lamb circulation. Acta Paediatr Scand 55:441-451

4. Soifer SJ, Loitz RD, Roman C, Heymann MA 1985 Leukotriene end organ antagonists increase pulmonary blood flow in fetal lambs. Am J Physiol 249:H570-H576

5. Harrison DG, Cai H2003 Endothelial control of vasomotion and nitric oxide production. Cardiol Clin 21:289-302

6. Heymann MA 1999 Control of the pulmonary circulation in the fetus and during the transitional period to air breathing. Eur J Obstet Gynecol Reprod Biol 84:127-132

7. Abman SH, Chatfield BA, Hall SL, McMurtry IF 1990 Role of endothelium-derived relaxing factor during transition of pulmonary circulation at birth. Am J Physiol 259:H1921-H1927

8. Grover TR, Zenge JP, Parker TA, Abman SH 2002 Vascular endothelial growth factor causes pulmonary vasodilation through activation of the phosphatidylinositol3-kinase-nitric oxide pathway in the late-gestation ovine fetus. Pediatr Res 52:907912

9. Haworth SG, Hislop AA 2003 Lung development-the effects of chronic hypoxia. Semin Neonatol 8:1-8

10. Minoo P 2000 Transcriptional regulation of lung development: emergence of specificity. Respir Res 1:109-115

11. Stenmark KR, Gebb SA 2003 Lung vascular development: breathing new life into an old problem. Am J Respir Cell Mol Biol 28:133-137

12. Hislop AA 2002 Airway and blood vessel interaction during lung development. J Anat 201:325-334

13. Hall SM, Hislop AA, Pierce CM, Haworth SG 2000 Prenatal origins of human intrapulmonary arteries: formation and smooth muscle maturation. Am J Respir Cell Mol Biol 23:194-203

14. Ivy DD, le Cras TD, Parker TA, Zenge JP, Jakkula M, Markham NE, Kinsella JP, Abman SH 2000 Developmental changes in endothelin expression and activity in the ovine fetal lung. Am J Physiol Lung Cell Mol Physiol 278:L785-L793
15. Ivy DD, Yanagisawa M, Gariepy CE, Gebb SA, Colvin KL, McMurtry IF 2002 Exaggerated hypoxic pulmonary hypertension in endothelin B receptor-deficient rats. Am J Physiol Lung Cell Mol Physiol 282:L703-L712

16. Ivy DD, Kinsella JP, Abman SH 1994 Physiologic characterization of endothelin A and B receptor activity in the ovine fetal pulmonary circulation. J Clin Invest 93:2141-2148

17. Ivy DD, Parker TA, Ziegler JW, Galan HL, Kinsella JP, Tuder RM, Abman SH 1997 Prolonged endothelin A receptor blockade attenuates chronic pulmonary hypertension in the ovine fetus. J Clin Invest 99:1179-1186

18. Ivy D, McMurtry IF, Yanagisawa M, Gariepy CE, Le Cras TD, Gebb SA, Morris KG, Wiseman RC, Abman SH 2001 Endothelin B receptor deficiency potentiates ET-1 and hypoxic pulmonary vasoconstriction. Am J Physiol Lung Cell Mol Physiol 280:L1040-L1048

19. Ivy DD, Lee DS, Rairigh RL, Parker TA, Abman SH 2004 Endothelin B receptor blockade attenuates pulmonary vasodilation in oxygen-ventilated fetal lambs. Biol Neonate 86:155-159

20. Levy M, Souil E, Sabry S, Favatier F, Vaugelade P, Mercier JC, Dall'Ava-Santucci J, Dinh-Xuan AT 2000 Maturational changes of endothelial vasoactive factors and pulmonary vascular tone at birth. Eur Respir J 15:158-165

21. Levy M, Maurey C, Chailley-Heu B, Martinovic J, Jaubert F, Isral-Biet D 2004 Developmental changes in endothelial vasoactive and angiogenic factors in the human perinatal lung. Pediatr Res 57:248-253

22. Waleh N, Kajino H, Marrache AM, Ginzinger D, Roman C, Seidner SR, Moss TJ, Fouron JC, Vazquez-Tello A, Chemtob S, Clyman RI 2004 Prostaglandin E2mediated relaxation of the ductus arteriosus: effects of gestational age on g proteincoupled receptor expression, signaling, and vasomotor control. Circulation 110:2326-2332

23. Fineman JR, Wong J, Morin FC III, Wild LM, Soifer SJ 1994 Chronic nitric oxide inhibition in utero produces persistent pulmonary hypertension in newborn lambs. J Clin Invest 93:2675-2683

24. Parker TA, le Cras TD, Kinsella JP, Abman SH 2000 Developmental changes in endothelial nitric oxide synthase expression and activity in ovine fetal lung. Am J Physiol Lung Cell Mol Physiol 278:L202-L208

25. North AJ, Star RA, Brannon TS, Ujiie K, Wells LB, Lowenstein CJ, Snyder SH, Shaul PW 1994 Nitric oxide synthase type I and type III gene expression are developmentally regulated in rat lung. Am J Physiol 266:L635-L641

26. Xue C, Reynolds PR, Johns RA 1996 Developmental expression of NOS isoforms in fetal rat lung: implications for transitional circulation and pulmonary angiogenesis. Am J Physiol 270:L88-L100

27. Arrigoni FI, Hislop AA, Pollock JS, Haworth SG, Mitchell JA 2002 Birth upregulates nitric oxide synthase activity in the porcine lung. Life Sci 70:1609-1620

28. Burri PH, Dbaly J, Weibel ER 1974 The postnatal growth of the rat lung. I. Morphometry. Anat Rec 178:711-730

29. Burri PH 1974 The postnatal growth of the rat lung. 3. Morphology. Anat Rec 180:77-98

30. Docimo SG, Crone RK, Davies P, Reid L, Retik AB, Mandell J 1991 Pulmonary development in the fetal lamb: morphometric study of the alveolar phase. Anat Rec 229:495-498

31. Tang JR, Markham NE, Lin YJ, McMurtry IF, Maxey A, Kinsella JP, Abman SH 2004 Inhaled nitric oxide attenuates pulmonary hypertension and improves lung growth in infant rats after neonatal treatment with a VEGF receptor inhibitor. Am J Physiol Lung Cell Mol Physiol 287:L344-L351

32. Namba T, Koike H, Murakami K, Aoki M, Makino H, Hashiya N, Ogihara T, Kaneda Y, Kohno M, Morishita R 2003 Angiogenesis induced by endothelial nitric oxide synthase gene through vascular endothelial growth factor expression in a rat hindlimb ischemia model. Circulation 108:2250-2257

33. Balasubramaniam V, Tang JR, Maxey A, Plopper CG, Abman SH 2003 Mild hypoxia impairs alveolarization in the endothelial nitric oxide synthase-deficient mouse. Am J Physiol Lung Cell Mol Physiol 284:L964-L971

34. Fagan KA, Fouty BW, Tyler RC, Morris KG Jr, Hepler LK, Sato K, LeCras TD, Abman SH, Weinberger HD, Huang PL, McMurtry IF, Rodman DM 1999 The pulmonary circulation of homozygous or heterozygous eNOS-null mice is hyperresponsive to mild hypoxia. J Clin Invest 103:291-299

35. Grover TR, Ackerman KG, Le Cras TD, Jobe AH, Abman SH 2000 Repetitive prenatal glucocorticoids increase lung endothelial nitric oxide synthase expression in ovine fetuses delivered at term. Pediatr Res 48:75-83

36. Acarregui MJ, Penisten ST, Goss KL, Ramirez K, Snyder JM 1999 Vascular endothelial growth factor gene expression in human fetal lung in vitro. Am J Respir Cell Mol Biol 20:14-23

37. Leung DW, Cachianes G, Kuang WJ, Goeddel DV, Ferrara N 1989 Vascular endothelial growth factor is a secreted angiogenic mitogen. Science 246:13061309

38. Ferrara N, Houck KA, Jakeman LB, Winer J, Leung DW 1991 The vascular endothelial growth factor family of polypeptides. J Cell Biochem 47:211-218

39. Boussat S, Eddahibi S, Coste A, Fataccioli V, Gouge M, Housset B, Adnot S, Maitre B 2000 Expression and regulation of vascular endothelial growth factor in human pulmonary epithelial cells. Am J Physiol Lung Cell Mol Physiol 279:L371-L378

40. Yamamoto K, Takahashi T, Asahara T, Ohura N, Sokabe T, Kamiya A, Ando J 2003 Proliferation, differentiation, and tube formation by endothelial progenitor cells in response to shear stress. J Appl Physiol 95:2081-2088

41. Lassus P, Turanlahti M, Heikkila P, Andersson LC, Nupponen I, Sarnesto A, Andersson S 2001 Pulmonary vascular endothelial growth factor and Flt-1 in fetuses, in acute and chronic lung disease, and in persistent pulmonary hypertension of the newborn. Am J Respir Crit Care Med 164:1981-1987 
42. Le Cras TD, Markham NE, Tuder RM, Voelkel NF, Abman SH 2002 Treatment of newborn rats with a VEGF receptor inhibitor causes pulmonary hypertension and abnormal lung structure. Am J Physiol Lung Cell Mol Physiol 283:L555-L562

43. Brown KR, England KM, Goss KL, Snyder JM, Acarregui MJ 2001 VEGF induces airway epithelial cell proliferation in human fetal lung in vitro. Am J Physiol Lung Cell Mol Physiol 281:L1001-L1010

44. Raoul W, Chailley-Heu B, Barlier-Mur AM, Delacourt C, Maitre B, Bourbon JR 2004 Effects of vascular endothelial growth factor on isolated fetal alveolar type II cells. Am J Physiol Lung Cell Mol Physiol 286:L1293-L1301

45. Sandri F, Ancora G, Lanzoni A, Tagliabue P, Colnaghi M, Ventura ML, Rinaldi M Mondello I, Gancia P, Salvioli GP, Orzalesi M, Mosca F 2004 Prophylactic nasa continuous positive airways pressure in newborns of 28-31 weeks gestation: multicentre randomised controlled clinical trial. Arch Dis Child Fetal Neonatal Ed 89:F394-F398

46. Escobedo MB, Gunkel JH, Kennedy KA, Shattuck KE, Sanchez PJ, Seidner S, Hensley G, Cochran CK, Moya F, Morris B, Denson S, Stribley R, Naqvi M, Lasky RE; Texas Neonatal Research Group 2004 Early surfactant for neonates with mild to moderate respiratory distress syndrome: a multicenter, randomized trial. J Pediatr 144:804-808

47. Dawes GS, Mott JC, Widdicombe JG, Wyatt DG 1953 Changes in the lungs of the new-born lamb. J Physiol 121:141-162

48. Velvis H, Moore P, Heymann MA 1991 Prostaglandin inhibition prevents the fall in pulmonary vascular resistance as a result of rhythmic distension of the lungs in fetal lambs. Pediatr Res 30:62-68

49. Cornfield DN, Chatfield BA, McQueston JA, McMurtry IF, Abman SH 1992 Effects of birth-related stimuli on L-arginine-dependent pulmonary vasodilation in ovine fetus. Am J Physiol 262:H1474-H1481

50. Liu SF, Hislop AA, Haworth SG, Barnes PJ 1992 Developmental changes in endothelium-dependent pulmonary vasodilatation in pigs. Br J Pharmacol 106:324-330

51. Hislop AA, Springall DR, Buttery LD, Pollock JS, Haworth SG 1995 Abundance of endothelial nitric oxide synthase in newborn intrapulmonary arteries. Arch Dis Child Fetal Neonatal Ed. 73:F17-F21

52. Banerjee A, Roman C, Heymann MA 1994 Bradykinin receptor blockade does no affect oxygen-mediated pulmonary vasodilation in fetal lambs. Pediatr Res 36:474480

53. Standen NB, Quayle JM $1998 \mathrm{~K}+$ channel modulation in arterial smooth muscle. Acta Physiol Scand 164:549-557

54. Mital S, Konduri GG 2000 Vascular potassium channels mediate oxygen-induced pulmonary vasodilation in fetal lambs. Biol Neonate 77:58-68

55. Sakai M, Unemoto K, Solari V, Puri P 2004 Decreased expression of voltage-gated $\mathrm{K}+$ channels in pulmonary artery smooth muscles cells in nitrofen-induced congenital diaphragmatic hernia in rats. Pediatr Surg Int 20:192-196

56. Cornfield DN, Resnik ER, Herron JM, Abman SH 2000 Chronic intrauterine pulmonary hypertension decreases calcium-sensitive potassium channel mRNA expression. Am J Physiol Lung Cell Mol Physiol 279:L857-L862

57. Cornfield DN, McQueston JA, McMurtry IF, Rodman DM, Abman SH 1992 Role of ATP-sensitive potassium channels in ovine fetal pulmonary vascular tone. Am J Physiol 263:H1363-H1368
58. Olschewski A, Hong Z, Linden BC, Porter VA, Weir EK, Cornfield DN 2002 Contribution of the $\mathrm{K}(\mathrm{Ca})$ channel to membrane potential and $\mathrm{O}_{2}$ sensitivity is decreased in an ovine PPHN model. Am J Physiol Lung Cell Mol Physiol 283:L1103-L1109

59. Pinheiro JM, Malik AB $1992 \mathrm{~K}+$ ATP-channel activation causes marked vasodilation in the hypertensive neonatal pig lung. Am J Physiol 263:H1532-H1536

60. Levy M, Maurey C, Advenier C, Israel-Biet D $2004 \mathrm{~K}_{\text {ATP }}$ channels: a crucial pathway for pulmonary hypertension of the newborn? Am J Resp Crit Care Med 169:A406

61. Levy M, Tulloh RM, Komai H, Stuart-Smith K, Haworth SG 1995 Maturation of the contractile response and its endothelial modulation in newborn porcine intrapulmonary arteries. Pediatr Res 38:25-29

62. Kasemsri T, Armstead WM 1997 Endothelin impairs ATP-sensitive K+ channel function after brain injury. Am J Physiol 273:H2639-H2647

63. Watanuki M, Horie M, Tsuchiya K, Obayashi K, Sasayama S1997 Endothelin-1 inhibition of cardiac ATP-sensitive $\mathrm{K}+$ channels via pertussis-toxin-sensitive Gproteins. Cardiovasc Res 33:123-130

64. Levy M, Chailley-Heu B, Israel-Biet D 2004 Ontogeny of endothelial and vasoactive factors in the human lung Am J Resp Crit Care Med 169:A22

65. Kinsella JP, Parker TA, Ivy DD, Abman SH 2003 Noninvasive delivery of inhaled nitric oxide therapy for late pulmonary hypertension in newborn infants with congenital diaphragmatic hernia. J Pediatr 142:397-401

66. Roberts JD Jr, Fineman JR, Morin FC III, Shaul PW, Rimar S, Schreiber MD, Polin RA, Zwass MS, Zayek MM, Gross I, Heymann MA, Zapol WM 1997 Inhaled nitric oxide and persistent pulmonary hypertension of the newborn. The Inhaled Nitric Oxide Study Group. N Engl J Med 336:605-610

67. Macrae DJ, Field D, Mercier JC, Moller J, Stiris T, Biban P, Cornick P, Goldman A, Gothberg S, Gustafsson LE, Hammer J, Lonnqvist PA, Sanchez-Luna M, Sedin G, Subhedar N 2004 Inhaled nitric oxide therapy in neonates and children: reaching a European consensus. Intensive Care Med 30:372-380

68. Olschewski H, Rose F, Schermuly R, Ghofrani HA, Enke B, Olschewski A, Seege W 2004 Prostacyclin and its analogues in the treatment of pulmonary hypertension. Pharmacol Ther 102:139-153

69. Sitbon O, Humbert M, Ioos V, Jais X, Hamid AM, Parent F, Herve P, Simonneau G 2004 Transition from intravenous epoprostenol to oral bosentan in pulmonary arterial hypertension. Am J Resp Crit Care Med 169:A176

70. Chin K, Channick R 2004 Bosentan. Expert Rev Cardiovasc Ther 2:175-182

71. Atz AM, Wessel DL1999 Sildenafil ameliorates effects of inhaled nitric oxide withdrawal. Anesthesiology 91:307-310

72. Ghofrani HA, Pepke-Zaba J, Barbera JA, Channick R, Keogh AM, Gomez-Sanchez MA, Kneussl M, Grimminger F 2004 Nitric oxide pathway and phosphodiesterase inhibitors in pulmonary arterial hypertension. J Am Coll Cardiol 43:68S-72S

73. Matsubara T, Minatoguchi S, Matsuo H, Hayakawa K, Segawa T, Matsuno Y, Watanabe S, Arai M, Uno Y, Kawasaki M, Noda T, Takemura G, Nishigaki K, Fujiwara H 2000 Three minute, but not one minute, ischemia and nicorandil have a preconditioning effect in patients with coronary artery disease. J Am Coll Cardiol $35: 345-351$ 